\author{
Aleksandar Fatić \\ Univerzitet u Beogradu, Institut za filozofiju i društvenu teoriju, Kraljice Natalije 45, RS-11000 Beograd \\ fatic@instifdt.bg.ac.rs
}

\title{
Predodžba i patologija u filozofiji i psihoterapiji
}

\begin{abstract}
Sažetak
U članku se razmatra shvaćanje mentalnog poremećaja kao predodžbe, na tragu epistemičkog naslijeđa Kanta i Schopenhauera, koje predstavlja sastavni dio suvremenog shvaćanja mentalnog zdravlja kao zdravog »narativa« ili životne priče. Nadalje, rad razmatra evoluciju razumijevanja bolesti u psihijatriji i postepeni povratak lacanovske psihoanalize i klasične psihijatrije, koje svojim ključnim pojmovima utiru put srastanju klasične psihoterapije i suvremene filozofske prakse u onome što se može nazvati integrativnom psihoterapijom.

Ključne riječi

integrativna psihoterapija, mentalni poremećaj, lacanovska psihoanaliza, filozofska praksa
\end{abstract}

\section{1. Što je uopće psihopatologija?}

Jedan stav, donekle kontroverzan, ali istovremeno uvjerljiv, u filozofski informiranoj psihoterapiji jest da je psihopatologija uvijek izbor. Ona je izbor na koji se osoba odlučuje u odsustvu drugih izbora. Osoba to čini nesvjesno i izuzetno joj je teško kasnije samostalno odustati od njega. Ovaj stav vjerojatno ima korijene u psihoanalizi i njoj svojstvenom traganju za načinima kojima bivše iskustvo utječe na sadašnje stavove, kognicije i dispozicije, a suštinski ide u suprotnost biološki orijentiranom razumijevanju mentalne bolesti kao biokemijskog ili neurološko-morfološkog fenomena. Shvaćanje mentalnog poremećaja, u širem, i mentalne bolesti (psihoze), u užem smislu, kao sistema uvjerenja koji predstavlja rezultat određene vrste osobnog, iako nesvjesnog izbora, otvara širok filozofski horizont za rad na psihopatologiji.

Razumijevanje mentalnih poremećaja, a naročito psihoze, kao osobnog izbora, a ne kao »bolesti«, rezultat je suvremenih istraživanja usmjerenih na provjeru metodološke održivosti psihijatrijskih medicinskih dijagnoza. Neka utjecajna i široko zasnovana istraživanja dovela su u pitanje samu opravdanost postojanja psihijatrijskih dijagnoza, naročito s točke gledišta praktičnih načina na koje se one donose. Za razliku od ostalih medicinskih dijagnoza, psihijatrijske se dijagnoze uglavnom ne mogu objektivno testirati biokemijskim nalazima ili upotrebom vizualne, ultrazvučne ili magnetne tehnologije, tako da se donošenje dijagnoza u praksi svodi na promatranje i zaključivanje na osnovi »simptoma«. Iako je u psihijatriji nejasno što je točno simptom, a što normalno ponašanje, uvjetno uzeto, normalno ponašanje postaje simptom onda kada počne smetati pacijentu, tj. kada se on »dekompenzira«. Primjera radi, čovjek koji je uznemiren ili pati od nekog straha samim time nije pacijent, niti ima 
mentalni poremećaj. Ukoliko on zbog tog straha manje spava i ranije ustaje kako bi nešto poduzeo da preduhitri opasnost koje se plaši,${ }^{1}$ utoliko to stanje nije patološko, iako mu manjak sna može prouzročiti teškoće. Ipak, ako se uznemirenost odrazi na njegov subjektivni doživljaj u mjeri da je on tumači kao »nenormalnu« ili ako mu se nedostatak odmora počne činiti kao ozbiljna životna smetnja, te stoga odluči otići na psihijatrijski pregled, on automatski postaje pacijent. Njegov manjak sna postaje »insomnia«, njegova uznemirenost postaje »anksioznost«, njegov strah od gubitka posla ili bankrota može postati »paranoičan«. I uznemirenost i manjak sna i strah tada postaju simptomi i pokreće se proces traganja za bolešću koja daje osnovu za takve simptome. Problem leži u činjenici da su psihijatrijske dijagnoze sasvim arbitrarne i zasnovane na osobnom stavu i načinu na koji psihijatar usmjerava svoju pažnju, pri čemu između različitih dijagnostičara nema ni bitnog slaganja u dijagnozama, ni objektivnog načina da se dijagnoze testiraju i potvrde. Istovremeno, psihijatrijske dijagnoze predstavljaju ozbiljne »etikete« koje donose stigmu i imaju dugoročne posljedice za daljnji život pojedinca.

Osamdesetih godina prošlog stoljeća, tim predvođen Van Lieshoutom proveo je istraživanje kojim je prema tri osi uspoređivanja usporedio način određivanja psihijatrijskih dijagnoza između različitih dijagnostičara:

(1) između dijagnoze prilikom prijema i dijagnoze prilikom otpusta iz bolnice u roku od godinu dana;

(2) između dijagnoze prilikom otpusta iz psihijatrijske bolnice i dijagnoze prilikom prijema u istu tu psihijatrijsku bolnicu, $\mathrm{u}$ vremenskom okviru od najviše godinu dana;

(3) između dijagnoze prilikom otpusta iz jedne psihijatrijske bolnice i dijagnoze prilikom prijema u drugu psihijatrijsku bolnicu, također u okviru od godinu dana.

Izvor za sve ove podatke bio je nizozemski »Patient Register of Intramural Mental Health Care« (PIGG). Zaključci ovog istraživanja bili su sljedeći:

(a) slaganje različitih dijagnostičara u pogledu PIGG dijagnoza za istog pacijenta u različito vrijeme bilo je minimalno;

(b) ovo neslaganje naročito je izraženo kod dijagnostičara koji su dijagnoze određivali neovisno o drugim dijagnostičarima (dakle, ne konzilijarno);

(c) istraživanjem su isključeni svi tehnički faktori koji bi mogli objasniti visoku vjerojatnost da će isti pacijent dobiti različite dijagnoze prilikom prijema u bolnicu u odnosu na dijagnozu prilikom otpusta iz prethodne bolnice (Van Lieshout et al., 1987).

Početkom sedamdesetih godina prošlog stoljeća, Rosenhan je izveo eksperiment $u$ dvije faze, kojim je pokazao arbitrarnost psihijatrijskih dijagnoza $u$ Americi. Rosenhan je u prvoj fazi poslao određeni broj ispitanika u različite američke psihijatrijske klinike s uputom da prilikom prvog pregleda prijave halucinacije, a da se nakon hospitalizacije ponašaju potpuno normalno te da na sva pitanja odgovaraju kao zdravi ljudi. Svi ispitanici bili su osobe bez ikakve povijesti mentalnih poremećaja, dakle nesporno »zdravi« ljudi. Svim ispitanicima, u svim klinikama, odmah su dijagnosticirani psihotični poremećaji i zadržani su u bolnici. Nakon dodatnih pregleda u bolnici, iako se radilo o zdravim ljudima koji su davali potpuno zdrave i normalne odgovore, svi dijagnostičari ostali su pri dijagnozi psihoze, a čak su pružili i detaljna objašnjenja zašto navodno ponašanje ispitanika nakon hospitalizacije potvrđuje inicijalne dijagnoze te su svi otpušteni iz bolnice s dijagnozama 
psihoze. Rosenhan je potom objavio imena ispitanika, što je izazvalo veliko javno uznemirenje među psihijatrima. Nakon kratkog vremena, Rosenhan je uznemirenoj psihijatrijskoj profesiji ponudio »drugu šansu«. Najavio je da će ponovo poslati ispitanike i ponoviti eksperiment kako bi definitivno potvrdio zaključke donesene na osnovi prvog eksperimenta. U narednim mjesecima, američke psihijatrijske klinike masovno su objavljivale da su otkrile »provokatore« $\mathrm{i}$ »lažne pacijente« te su pacijente s navodnim simptomima psihoze otpuštale kao zdrave ljude. Nakon što su svi ovi izvještaji pristigli, Rosenhan je obavijestio javnost o podacima iz kojih se vidi da nije poslao ni jednog ispitanika u ni jednu kliniku. Dakle, ljudi koji su vraćeni kao »lažni pacijenti« i kao »zdravi« bili su ustvari »pravi« pacijenti sa stvarnim simptomima psihoze (Rosenhan, 1973; 1975).

Iako ovi eksperimenti ne predstavljaju konkluzivan logički dokaz da psihijatrijske dijagnoze ne odgovaraju nekoj psihičkoj »stvarnosti«, oni svakako dovode u sumnju pouzdanost tih dijagnoza, kao i validnost dijagnostičkih postupaka sâme metodologije koja stoji iza suvremene psihijatrije. Stoga je jedan od zaključaka koji se mogu pouzdano izvesti iz ovih i sličnih empirijskih eksperimenata taj da psihijatrijske dijagnoze i klasifikacije nisu prave medicinske dijagnoze jer se ne mogu potvrditi objektivnim znanstvenim metodama, ${ }^{2}$ nego da naprosto predstavljaju termine kojima se psihijatrija služi u nedostatku boljih načina komunikacije. Veliko je pitanje jesu li psihoze zaista bolest ili nešto drugo, kao što je veliko pitanje i koliko je uopće korisno koristiti postojeće klasifikacije i truditi se da se mentalne teškoće dijagnosticiraju po medicinskoj metodologiji?

Razlozi za sumnju u primjerenost medicinskog modela dijagnosticiranja bolesti djelomično leže i u samoj logici medicinske dijagnostike, s jedne strane, i logici psihodijagnostike, s druge strane. Kako se ispostavlja, ove dvije logike ne samo da su različite nego su i dijametralno suprotne, što čini neodrživim shvaćanje da psihodijagnostika uopće može biti dio medicinske dijagnostike te da se mjesto psihijatrije kao discipline uopće nalazi u okviru medicinske znanosti. Suprotnosti u logici između medicinske dijagnostike i psihodijagnostike leže prije svega u ulozi koju u tim procesima imaju pojedinačno i opće, odnosno dijalektičko kretanje od pojedinačnog k općem i obrnuto.

Simptom bolesti u medicinskoj dijagnostici nešto je što se tretira kao pojedinačno te simptom kao takav ukazuje na neku opću stvarnost koju predstavlja bolest. Tako svi pacijenti koji imaju određene bitne simptome neke bolesti vjerojatno imaju tu bolest: ako više ljudi ima povišenu temperaturu, kašalj i pokazuje znakove fizičke iscrpljenosti, ti simptomi mogu (ako se potvrde biokemijskim nalazima krvi i drugim vrstama pregleda) ukazivati na činjenicu da sve te osobe boluju od gripe ili od upale pluća ili od nekog drugog respiratornog oboljenja. Dijalektičko kretanje u medicinskoj dijagnostici kretanje je od pojedinačnog (simptom) k općem (bolest). Liječenje je tipizirano za određene bolesti (uz odstupanja prema specifičnosti pojedinih pacijenata), tako da je dijagnoza bolesti preduvjet za poduzimanje racionalnog liječenja.

U psihodijagnostici, dijalektika je pojedinačnog i općeg suprotna. Kod mentalnih teškoća (namjerno ih ne nazivam mentalnim poremećajima) simptom je nešto opće. Ako jedna osoba ima neki izražen strah ili pati od bezvoljnosti ili je previše aktivna, ona taj simptom može ispoljavati zbog traume uzrokovane prošlim iskustvom, zato što je izložena pretjeranoj stimulaciji ili zato što

Recimo bankrota firme ili gubitka zaposlenja. Biokemijskim analizama, fMRI skeniranjem ili upotrebom ostalih tehnika. 
pati od onoga što konvencionalna psihijatrija naziva bipolarnim poremećajem. Različite »bolesti« u psihodijagnostici daju iste simptome. Kao i medicinska dijagnostika, psihodijagnostika polazi od simptoma, ali se - suprotno medicinskoj dijagnostici - ne kreće od simptoma kao pojedinačnog faktora $\mathrm{k}$ bolesti kao općem, već naprotiv, simptom tretira kao nešto opće i nastoji razlučiti koji »poremećaj« od mnogih koji daju te simptome može biti prisutan kod pacijenta ili klijenta. Pri tome, riječi koje se u psihijatriji koriste za »bolesti« nisu dijagnoze nego klasifikacije, koje su uvjetne. Dijagnoze su opisne i one uključuju šire razumijevanje konkretnog stanja u kojemu se čovjek nalazi: traumatiziranost, osjećaj izoliranosti od stvarnosti, frustrirana potreba za drugima i za podrškom itd. Svaka osoba na taj način, idealno, dobiva različitu i nijansiranu psihijatrijsku »dijagnozu«, a više takvih dijagnoza se, prakse radi, uklapa u slične »klasifikacije«, koje su sve, nakon istraživanja poput dva ranije navedena, dovedene u sumnju (Verhaeghe, 2018: 3-10).

Stoga su sumnjivost psihijatrijske dijagnostike i klasifikacije višestruko zasnovane na pretenziji psihijatrije da bude »medicinska« disciplina, što ona po svom sadržaju jamačno nije, ne samo zbog toga što joj nedostaju objektivna sredstva verifikacije nego i zbog same logike psiho-dijagnostike. Ova sumnjičavost glede psihijatrije kao discipline otvara pitanje šire humanističke interpretacije njezinih osnovnih kategorija, kao i pitanje o ulozi filozofije i filozofski informirane psihoterapije u eventualno kvalitetnijem, delikatnijem i praktično efikasnijem tretiranju mentalnih teškoća. Da bi se moglo doći do zaključaka o takvoj ulozi primijenjene filozofije prethodno valja iz nemedicinske, dakle humanističke perspektive, razmotriti alternativno razumijevanje mentalnih poremećaja, a posebno psihoza.

\section{Ključni elementi konvencionalnih predodžbi o psihozi}

Jedan od bitnih elemenata konvencionalnog razumijevanja zdrave psihe je pretpostavka o njenoj »stvarnosnosti«. Pretpostavlja se da zdrava psiha na neki način adekvatno »korespondira« sa stvarnošću u smislu da ima »realističan « zahvat stvarnosti u svojoj percepciji i djelovanju. Drugi bitan element tog konvencionalnog razumijevanja jest shvaćanje adekvatne koherencije, to jest spoznaja da su shvaćanja i stavovi zdrave psihe u nekoj vrsti sklada s bitnim shvaćanjima i stavovima drugih ljudi, kao i sa prevladavajućim razumijevanjem činjenica. Riječ je o kombinaciji dva tradicionalna filozofska kriterija »istinitosti«: jedan je pretpostavljena korespondencija sa stvarnošću (istinito je ono što odgovara stvarnosti), a drugi usklađenost percepcije ili stava s drugim »istinitim« percepcijama ili stavovima, tako da postoji neka vrste koherentnog sistema vjerovanja koji je »realan«, a samim time i »istinit«.

Sumiranu formulaciju ovog oslanjanja konvencionalnog razumijevanja zdrave psihe na korespondentnu i koherentističku epistemologiju ponudila je Marya Schechtman u svom obrazloženju uvjeta za zdrav osobni narativ. Schechtmanova govori o »uvjetu realiteta«, koji podrazumijeva da su »bitni elementi osobnog narativa u skladu s ključnim spoznajama o stvarnosti koje dijele ostali ljudi «, ${ }^{3}$ te o »uvjetu artikulacije« kao sposobnosti ličnosti da dovoljno artikulirano predoči svoj narativ. Svaki poremećaj realiteta ili artikulacije sugerira mogućnost mentalnog poremećaja i potrebu za psihoterapeutskim djelovanjem kako bi se time poremećeni narativ korigirao (Schechtman, 2011).

Pod uvjete artikulacije, prema formulaciji Schechtmanove, spada i simptom disocijacije, odnosno nesklad između kognicije i emocija, odnosno spoznaj- 
nog sadržaja koji se saopćava u sklopu narativa i emocija koje prate to saopćavanje. Ova vrsta sumiranja korespondentno-koherentističke prirode psihodijagnostike $\mathrm{u}$ formi ocjene narativa ukazuje na bitne filozofske probleme koji u konvencionalnom shvaćanju mentalnog zdravlja uopće nisu konstatirani, a koji ukazuju na specifično »objektivističko« shvaćanje svijesti, a samim time i patologije.

\section{Problemi s objektivističkim shvaćanjem patologije}

U modernoj filozofiji, barem od Kanta, teorija korespondencije dovedena je u pitanje kao teorija spoznaje, a i kao teorija istine. Kant je, opisujući »objektivnu« stvarnost kao »stvar po sebi«, ukazao na a priori uvjete spoznaje koji »lome« sliku objektivne stvarnosti i pretvaraju je u predodžbu u svijesti subjekta, pri čemu tu predodžbu organiziraju prostor i vrijeme kao a priori uvjeti spoznaje koji prebivaju u samoj svijesti, a ne u stvari po sebi van svijesti. Stoga opažanje, koje je organizirano koordinatama prostora i vremena, ne odražava objektivnu stvarnost, već je obrađuje. Može se pretpostaviti da bi se ista logika mogla primijeniti i na druge a priori uvjete spoznaje, ali također i doživljavanja u širem smislu, iz čega proizlazi danas klasični stav u epistemologiji da ne postoji način utvrđivanja je li ono što doživljavamo »realno« ili je manje realno. Kantovom epistemološkom argumentacijom ustvari je u modernoj zapadnoj intelektualnoj tradiciji ukinuta mogućnost jednostavnog korespondentnog shvaćanja spoznaje i istine.

Istovremeno, koherentističko shvaćanje spoznaje preživjelo je Kantov »kopernikanski obrat«, ali samo kao praktični, pragmatični kriterij ocjene subjektivnih doživljaja. Kant inzistira na tome da kontinuitet iskustva izvanjskog svijeta koji pobuđuje unutrašnje doživljaje prethodi mogućnosti imaginacije, pa i sanjanja tog svijeta ili tih iskustava, tako da u doživljajnom smislu strukturne kvalitete doživljaja (dugotrajnost i koherentnost) odlučuju o tome radi li se o iskustvu izvanjskog svijeta ili čisto unutrašnjem iskustvu (Kant, 1956: 60-64).

Kant bi na pitanje u čemu se naši doživljaji na javi razlikuju od naših doživljaja u snu, kada ni jedni ni drugi ne odražavaju nužno neku nezavisnu, objektivnu »stvarnost«, vjerojatno odgovorio da je jedini način za razlikovanje sna od jave koherencija doživljaja; uspoređivanjem slijeda doživljaja i predodžbi može se zaključiti da je čovjek u nekom trenutku počeo sanjati, a potom se probudio iz sna. Ukoliko sada, tipkajući za računalom doživim da se iznenada nalazim na plaži, a potom se poslije nekog vremena neobjašnjivo ponovo nađem ispred računala, utoliko ću vjerojatno zaključiti da je plaža san, a rad za računalom stvarnost zato što se ono prvo dogodilo iznenada, usred doživljaja pisanja i potom se prekinulo, dok se doživljaj pisanja nastavio. Osim toga, sada je zima i nije logično da sam se našao na plaži, a ne sjećam se ni priprema ni prijevoza do plaže, što znači da je sunčanje bilo san, a pisanje u kišnom zimskom gradu je java (Schopenhauer, 1969: 45-47).

Ako se razlika između subjektivnog doživljaja ili predodžbe jave, s jedne strane, i sna, s druge strane, ne sastoji od bilo kakvih kvaliteta čulnih opažanja ili doživljaja u cjelini, nego samo u njihovim vanjskim osobinama, to jest u koherenciji između njih i ostalih iskustava, onda se postavlja pitanje

Dakle, da nečiji narativ ne odudara od onoga

što ostali smatraju neospornim činjenicama. 
o metafizičkom statusu duševne bolesti kao stanja izmještene ili pomaknute svijesti i doživljajnosti. Ako se kvaliteta subjektivnog doživljaja zdrave osobe ne razlikuje od kvalitete subjektivnog doživljaja psihotične osobe, te ako se percepcija u zdravom stanju po kvaliteti ne razlikuje od percepcije u psihozi, može li se onda usporediti sa snom? I ako je psihoza neka vrsta doživljajnog sna, je li moguće probuditi se iz tog sna i shvatiti da je to bio san?

Ova u osnovi kantovska ideja o identičnosti kvaliteta doživljaja i mentalnih stanja u širem smislu, bez obzira na njihovu »realističnost « i »koherentnost«, u osnovi dovodi u pitanje metafizičku održivost ideje o »mentalnoj bolesti«. Ako se mentalna bolest metafizički ne razlikuje od mentalnog zdravlja na način na koji se, recimo, tumor metafizički razlikuje od zdravog tkiva, onda je pitanje može li se takvo mentalno stanje opravdano smatrati bolešću, ili naprosto jednim različitim stanjem, raspoloženjem i sistemom uvjerenja od onog koje je uobičajeno, na isti način na koji je moj prelazak u san o plaži usred pisanja ovog teksta samo jedno različito stanje (san) u odnosu na budno stanje (java), pri čemu se san po kvaliteti doživljaja nužno ne razlikuje od jave. Buđenje iz sna psihoze kao paradigma je sasvim različito od »liječenja psihoze« lijekovima: buđenje je stvar uspoređivanja senzacija i uvjerenja, preispitivanja njihove validnosti, korisnosti i zadovoljstva koju ona donose. Drugim riječima, buđenje iz sna psihoze možda je stvar kritičkog preispitivanja. Ono može biti stvar filozofije prije nego medicine, premda filozofija naravno ne isključuje medicinu, niti medicina isključuje filozofiju, naprotiv (Raabe, 2014).

\section{Predodžba kao forma znanja i izvor zadovoljstva (Lacanov jouissance)}

Vjerojatno najvažniji filozof Moderne, koji je odnos subjektivizma i objektivizma formulirao na način svojstven suvremenoj terapeutski orijentiranoj filozofiji, bio je Arthur Schopenhauer. Schopenhauer koncipira realizam kao sredinu između subjektivizma i objektivizma. Za njega je predodžba jedina stvarnost koja određuje kvalitetu života, a proces koji dovodi do formiranja predodžbe on naziva »percepcijom«. Percepciju shvaća daleko šire od suvremenog razumijevanja percepcije kao »čulnog doživljaja« koji je, u pojmovnom smislu, različit od kognicije. Za Schopenhauera, percepcija uključuje i neke forme znanja jer se bez prethodnog znanja čulni podaci ne mogu adekvatno organizirati u smislene predodžbe. Ona uključuje i neke vrste stavova jer ti stavovi pomažu u stabiliziranju predodžbe. Stoga je, u Schopenhauerovoj vizuri, granica između percepcije i drugih mentalnih funkcija fluidna. Slično tome, fluidna je i uvjetna i razlika između realnog i nerealnog, između adekvatne i neadekvatne predodžbe. Ono što određuje kvalitetu predodžbe jednako je interpretacija čulnih podataka i utisaka koliko i njihov sadržaj (Schopenhauer, 1969, knjiga 1). Stoga bi se moglo zaključiti da je pravljenje razlike između zdravih i bolesnih doživljaja i predodžbe ustvari interpretacija koja je po sadržaju zauzimanje stava: neke predodžbe i doživljaji čine nam se toliko neprihvatljivim i nesuglasnim s našim osobnim stavovima da smo ih skloni okarakterizirati kao »bolesne«. Ukoliko je neslaganje s dominantnim stavovima i vrijednostima dovoljno radikalno, utoliko postoji velika vjerojatnost da će nositelj takvih uvjerenja dobiti oznaku »bolestan«, na isti način na koji se ispoljava prirodna tendencija da teške zločine automatski smatramo djelima "poremećenog uma«. U slučaju mentalne disonance između dominantnog (u smislu uobičajenog) i različitog (neuobičajenog), ovaj se refleks patologiza- 
cije različitosti izražava u mekoj represiji kroz stigmatizaciju psihijatrijskim dijagnozama i kroz medicinski tretman koji je nerijetko prinudan.

U perspektivi lacanovske psihoanalize i klasične psihijatrije (kojoj je ta psihoanaliza bila bliska), a koja se sada vraća na medicinsku scenu s radovima novih lacanovaca među terapeutima (npr. Redmond, 2014), naglašen je značaj interpretacije mentalnih stanja, a smanjen značaj njihove patologizacije. U kontekstu lacanovske psihoanalize, psihoza ne prebiva u poremećenom kontaktu između osobnosti i Realnog (neposredne stvarnosti). Naprotiv, ona prebiva u nefunkcionalnom i nedovoljno bogatom Simboličkom (simboličkom svijetu osobnosti). Zdravlje osobnosti konstituira se kroz konstruktivne simboličke interpretacije neposrednih iskustava (Realnog) jer za većinu ljudi Realno je suštinski nepodnošljivo. Stoga Lacan smatra da je upravo direktan kontakt s Realnim, u nedostatku dovoljno artikuliranog Simboličkog, korijen psihoze. Izvor psihoze je negativan utjecaj Realnog. Psihoza je odgovor osobnosti na neposredno iskustvo koje osobnost ne može metabolizirati, dok bogato Simboličko daje osobnosti resurse kojima može savladati neizrecivu patnju i strah koje donosi kontakt s Realnim. Psihoza je upravo rezultat nemogućnosti osobnosti da savlada primordijalnu patnju i strah sadržane u Realnom.

Neuroza je, kao i psihoza, naprosto rezultat specifične konceptualne dijalektike koja organizira naše iskustvo. ${ }^{4}$ To se možda najbolje vidi u Lacanovu objašnjenju anksioznosti. On anksioznost prvo pojmovno povezuje s brigom (Sorge) u Heideggerovu smislu, dakle s egzistencijalnom »brižnošću«, da bi je potom situirao u kontekst drugog dopunskog signifiera, naime inhibicije. Anksioznost nastupa u svjetlu ta dva signifiera, u situaciji egzistencijalne zabrinutosti koju prati inhibiranost djelovanja. Potom Lacan ide korak dalje pa inhibiranost interpretira kao onemogućenost kretanja, sugerirajući da je mentalno zdravlje, kao i život uopće, povezano s kretanjem, dok je onemogućenost kretanja izvor obolijevanja. Tako onemogućenost postaje dodatni signifier koji u stvari inhibira životnost, mogućnost da se djeluje i time generira anksioznost (Lacan, 2014: 15-25). Psihoza nastupa tamo gdje se niz različitih signifiera ukrste na način koji ličnosti onemogućava da metabolizira iskustvo: ona je uvijek mogućnost svugdje gdje postoji neuroza, a moglo bi se reći da neuroza obitava u svima nama najveći dio vremena. Stoga je psihoza latentna mogućnost za sve nas, ne samo u teorijskom smislu nego i u iskustveno sasvim realnom smislu.

Prvi je uvjet razvoja otpornosti određene osobnosti na psihozu socijalizacija u kojoj ključnu ulogu igra funkcija koju Lacan naziva »ime oca«. To je uloga koju u razvoju djeteta prije svega igra otac kao socijalizator, zakonodavac i edukator. Ukoliko je funkcija »ime oca « blokirana ili uništena, ${ }^{5}$ a istu tu funkciju nije preuzeo netko drugi (u nekim slučajevima i majka), utoliko postoje svi preduvjeti da osobnost ne formira resurse potrebne za suočavanje s Realnim i da postane psihotična. Drugi je uvjet za suprotstavljanje psihozi obrazovanje i razvijanje dobrih komunikacijskih vještina.

Lacan je inzistirao na traženju »latentne psihoze« na početku psihoterapije. Psihoza nije samo patološko stanje nego je, prije svega, i egzistencijalno stanje sviju nas. Kao mogućnost, uvijek je tu. Stoga destigmatizacija psihoze ide ruku pod ruku s njenim ranim prepoznavanjem i psihoterapeutskim djelova- 
njem. Time se psihoza iz latentne, ne-manifesne faze ${ }^{6}$ razvije u manifestnu, tešku psihozu, kada je današnja pozitivistička psihijatrija tek prepoznaje, klasificira i »liječi« (Wolf, 2015: 72-75).

Lacanovska psihoanaliza kao alternativa pozitivističkoj psihijatriji svojim povratkom na psihoterapeutsku scenu ilustrira zašto je psihoterapija gotovo spontano evoluirala natrag u filozofiju u formi filozofske prakse. Jedan od argumenata navodi Bogdan Wolf pišući da je psihički događaj oko kojeg se formira neka patologija uvijek određena vrsta jezika koja nosi svoje značenje te je nekome namijenjena i ima svoju strukturu. Tako, na primjer, trauma koja potječe iz toga što smo kao dijete trpjeli nasilje, može proizvesti patologiju u odraslo doba iz razloga što je nasilje u djetinjstvu jezik. Razlog patologiji je u tome što dijete tom jeziku ne može dati simbolički smisao pa se izravno susreće s Realnim u nasilju, što ga rastrojava i traumatizira. Kasnije isto to dijete, kao odrastao čovjek, razvija sposobnosti i resurse interpretacije jezika nasilja, koje je trpjelo u djetinjstvu, i time se oslobađa patologije koja je, ustvari, obrana zdrave osobnosti od nepodnošljivog Realnog. Problem u terapiji nastaje zbog toga što je kontakt s Realnim već izazvao traumu. Time je početak suočavanja sa starim iskustvom, koji je prvi korak k reinterpretaciji tog iskustva, iznova uvijek bolan i neugodan: čovjek se radije ne bi upuštao $\mathrm{u}$ taj proces ako baš ne mora. Otpor prilikom terapije može se pripisati strahu od neprocesuiranog Realnog koje nas je jednom već povrijedilo; korist od psihoterapije leži u obogaćivanju Simboličkog. Upravo zato je opravdano shvaćanje terapije kao obrazovanja: što više osobnost zna o osobnim tegobama, ali i o teorijskim i iskustvenim perspektivama svog problema, to će više imati simboličkih resursa za obrađivanjem nepodnošljivog iskustva i davanjem značenja istom. Tako i odrastao čovjek, vraćajući se svojoj traumi koju je doživio kao dijete, sada daje značenje nasilju koje je trpio i samim tim uspostavlja kontrolu nad tim iskustvom te njime može upravljati i ispoljavati moć u odnosu na njega (Wolf, 2015: 20). Sve te promjene dovode do toga da iskustvo prestane biti trauma te naprosto postane jedno od mnogih iskustava koja imaju svoje značenje u našem osobnom narativu u svrhu definiranja našeg identiteta odrasle osobe. Netko tko je trpio nasilje kao dijete svoju nekadašnju traumu može, kada joj da odgovarajuće značenje, pretvoriti u vrijedno iskustvo i time postati »ekspert po iskustvu« za pitanja nasilja, pisac koji drugima daje simboličke resurse da se suprotstave traumatiziranju, psihoterapeut itd.

Razumijevanje ponašanja ili iskustava kao jezika podrazumijeva specifičnu filozofsku perspektivu koja nije svojstvena psihijatriji. Sukladno tome, psihijatriji nije prirodno da različitost, koju klasificira kao duševnu bolest, tretira kao jezik i da taj jezik (koji je uglavnom različit kod svakog pojedinca) uvijek iznova interpretira. Njoj je naprotiv, kao disciplini koja sebe razumijeva iz medicinske vizure, svojstveno da ponašanje, to jest slova i riječi tog jezika, tretira kao simptome, kao pojedinačno u odnosu na nešto opće (bolest) i da umjesto da se trudi iskomunicirati sa subjektom tog jezika (a to pretpostavlja kvalitetnu interpretaciju jezika) sam pokušaj korištenja drugog jezika opiše kao bolest. Kada se jedan nerazumljiv jezik označi kao bolest, time se faktički zaustavlja svaka mogućnost komunikacije jer »bolest« je nešto onostrano, $\mathrm{s}$ one strane razuma, s čim komunikacija uglavnom nema smisla, a može biti i opasna.

Druga strana ovakvog razumijevanja mentalnih tegoba ukazuje na činjenicu da je i odnos prema različitim ljudima koji imaju mentalne tegobe također jezik: to je jezik društva pa i struke, koji može biti i često je daleko više 
patološki nego mentalne smetnje od kojih pate oni »različiti«. Sklonost da se različito i nerazumljivo opiše kao patološko može se i sâma tretirati kao patologija pa u tom kontekstu i kao neka vrsta totalitarizma koja nije svojstvena tolerantnom i pluralnom društvu. Ako se pođe od pretpostavke da je psihopatologija ustvari jezik kojim osobnost izražava svoju nesposobnost da se suoči s Realnim, odnosno ako je psihopatologija domena Simboličkog koji nije dovoljno artikuliran i usmjeren, onda bi logično bilo pretpostaviti da način tretmana tih nedostataka u Simboličkom mora i sam biti simbolički, to jest mora uključivati neki kreativan pristup. Jezik koji može pomoći stoga posjeduje snažne simbole koji pomažu povratku na utabani put, tj. poput svjetionika daju orijentaciju drugoj osobi kako da sagleda svoj sudar s Realnim i kako da ga ugradi u ukupnost svog životnog iskustva bez kompenzatorskog narativa bolesti. Upotreba jezika kemije, prinudne hospitalizacije i odbijanja komunikacije, s druge strane, osiromašuje pacijentovo Simboličko, dodatno ogoljuje nepodnošljiv kontakt s Realnim i u cjelini pogoršava njegovo životno iskustvo. Predodžba života hospitaliziranog psihijatrijskog pacijenta je predodžba lišenosti, nerazumljivosti, obilježenosti i odbačenosti. Ta predodžba akutizira neposredovan dodir s Realnim. Upravo stoga i ima smisla govoriti o ljudima koji su »survivors of mental health care «, ${ }^{7}$ radije nego njeni korisnici: na neki način, naše označavanje mentalne bolesti kao takve donosi neku vrstu osjećaja osobne ispravnosti i »zdravlja« naše osobne psihe. Postoji jedna vrsta zadovoljstva u označavanju ljudi kao mentalno bolesnih kojom se izbjegava samoupitanost većine:

»Histeričar to 'zna' od samog početka, i ne znajući to, a Freud je to morao znati ukoliko je praksu psihoanalize utemeljio počevši s prijenosom na svoju histeriju. Ali svaki subjekt je histerični subjekt, samo što to neki ne žele znati, a drugi to spoznaju tek kasnije. Nema spoznaje o patnji subjekta, slabosti koja ga pretvara u zloglasnog glumca ili žrtvu koja traži naknadu, osim onoga što proizlazi iz želje i zadovoljstva Drugog, koje se zove jouissance.« (Wolf, 2014:14)

Lacanov pojam jouissance odnosi se na intersubjektivne odnose, a posebno na odnos između terapeuta i pacijenta. Ovdje taj odnos možemo promatrati široko, kao odnos između konsenzualne većine koja je »normalna« i manjine koja spada u domenu »neuroraznolikosti«, a koju označavamo kao »mentalno oboljelu«. Ta manjina predstavlja Drugog, a njena patnja, kada je formulirana kao bolest, donosi ohrabrenje Prvima i istovremeno im stvara poseban jouissance, tj. posebnu zadovoljštinu koja uključuje mnogo elemenata. Jedan takav element je uvjerenje da mi sâmi »nismo bolesni« ako su »oni bolesni«, iako je sadržaj tog uvjerenja epistemološki duboko sporan (»svaki subjekt je histerični subjekt, samo neki toga nisu svjesni«). Drugi elementi uključuju potvrdu ispravnosti dominantnih stavova, konceptualizacije odnosa u društvu, razumijevanja optimalne kvalitete života itd. Sva ova uvjerenja mogla bi biti osporena kada bi se neuroraznolikost shvaćala ozbiljno i kada bi se mentalna bolest tretirala kao epistemički izazov za sve članove društva: jesu li, možda, oni Drugi u pravu? To je veliko neupitano pitanje koje stoji iza mentalne bolesti, a koje se ne može jednostavno eliminirati ukazivanjem na površinsko estetsko uznemirenje koje izaziva postupanje onih koji pate od neposredovanog kontakta s golim iskustvom, nesposobni da ga simbolički osmisle. Možda je njihova sposobnost za empatiju, njihova osjetljivost, ali i njihova vizura

Kada ima samo blage forme i ukazuje na pokušaje osobnosti da formiranjem alternativne ideacije i sistema uvjerenja prebrodi nepodnošljiv kontakt s Realnim.
7

Osobe koje su preživjele sustav skrbi o mentalnom zdravlju. 
vrijednosti ispravnija od većinske i dominantne? Na kraju, zar je bilo malo pripadnika epistemičkih manjina koji su stradali, da bi se kasnije ispostavilo da je nemoralna, zla ili bolesna zapravo bila većina? Dovoljno se sjetiti sovjetskih Gulaga u kojima je, kao epistemički neistomišljenik, robijao jedan Solženjicin uz desetine tisuća drugih nevinih ljudi, ali i brojnih drugih zatvora i psihijatrijskih ustanova u kojima su bili izdvojeni najbolji članovi društva, književnici, umjetnici, mnogi psihijatri, filozofi i drugi intelektualci? Fenomen viktimizacije epistemičke manjine, uz izvjestan »zdravi« jouissance ne samo da nije ništa novo nego je masovno prisutan kroz čitavu povijest i sigurno ga možemo locirati u brojnim sadašnjim praksama europskih društava.

U kontekstu jouissance može se vidjeti djelomično služenje predodžbe u ostvarivanju osobnog zadovoljstva: kao što je predodžba svijeta i stvarnosti kod »psihotičnog« čovjeka velikim djelom usmjerena na to da osobi ponudi olakšanje od neposredovanog kontakta s Realnim, dakle da mu osigura neku razinu zadovoljstva usprkos nepodnošljivosti Realnog, tako je isto i naša predodžba o psihozi djelomično usmjerena na to da nam ponudi satisfakciju, obično u formi gratifikacije da smo »mi OK«. Problem s tom gratifikacijom jest u tome što podrazumijeva da, ako smo »mi OK«, nužno oni drugi »nisu $\mathrm{OK} \lll \mathrm{i}$ da se nekom vrstom imitiranja medicinske dijagnostike u formi psihijatrijske dijagnostike može napraviti granica između mentalnog zdravlja i mentalnog poremećaja. Dakle, sama koncepcija mentalnog poremećaja jest opažanje koje, među ostalim, služi i tome da se postigne zadovoljstvo samoodobravanja za većinu. Tako je, recimo, socijalno prihvatljivije da se netko u društvu napije i bude agresivan, da vrijeđa prisutne, dominira razgovorom, postupa neukusno i generalno govoreći ugrožava druge, nego da netko drugi, neki »shizofreničar«, u tom istom društvu neupadljivo sjedi i djeluje odsutno. Ovo prvo ponašanje otpisuje se kvalifikacijom »pijanstvo«, dok se ono drugo stigmatizira navodnom klasifikacijom »shizofrenija«. Kao što je o tome pisao Peter Raabe, psihijatrijske dijagnoze nisu ništa druge nego taksativni opisi ponašanja ljudi, pri čemu se neke forme ponašanja označavaju kao patološke. Ako je tako, onda je sasvim nejasno zašto je ponašanje jednog klasičnog "shizofreničara u u bilo kojem smislu više patološko nego ponašanje nekoga tko se napije ili naprosto nekoga tko je agresivna i uznemiravajuća osoba. Razlika je u činjenici da »shizofreničar « u strukturno većoj mjeri ne sudjeluje u zajedničkom svijetu koji grupa dijeli: njegov jouissance ga izdvaja iz tog svijeta koji ga uznemirava i uzrokuje mu patnju. Svako izdvajanje iz zajedničkog svijeta, s druge strane, kod grupe izaziva osjećaj zebnje i potrebe da se onaj koji ne prihvaća zajednički duh i način postojanja označi kao »loš« ili, u novije vrijeme, »bolestan«. Ta zebnja manifestira se i u nesklonosti većine ljudi da uopće borave u blizini nekoga tko je opisan kao »duševni bolesnik«, iako ta osoba možda u nekom trenutku uopće ne ispoljava nikakvo neobično ponašanje. Grupa je nemilosrdna i sve one pojedince čiji senzibilitet ne pripada senzibilitetu grupe ili izolira ili stigmatizira ili progoni.

\section{Srastanje tradicionalne psihoterapije s filozofskom praksom}

Lacanovska psihoanaliza, a posebno njezini suvremeni predstavnici, velikim su dijelom zaslužni za suvremeno srastanje tradicionalne psihoterapije s filozofskom praksom u onome što se može nazvati integrativnom psihoterapijom. Tradicionalna psihoterapija se, naime, suočila s dvije osnovne slabosti osobne predodžbe o sebi: prva je ideja da »škole« i »pravci« nešto znače za 
uspješnost psihoterapije, a druga je da je moguće voditi kritički diskurs o predodžbama koje čine naše živote, a time i stvarnost onih koje psihijatrija smatra duševno bolesnima, bez i izvan filozofije. Tradicionalna psihoterapija priznaje da je filozofija njezino tkivo. Npr. Eric Berne, osnivač transakcijske analize, sebe je smatrao »fenomenološkim filozofom «, a ne psihoterapeutom, a slično se može reći i za Carla Rogersa, Carla Gustava Junga i mnoge druge, dok se pojedine psihoterapeutske »škole« eksplicitno pozivaju na konceptualne osnove pojedinih filozofskih tradicija, poput stoičkih korijena kognitivno-bihevioralne terapije, danas jedne od najpopularnijih psihoterapeutskih metoda. Međutim, sve do kraja prošlog stoljeća i do pojave grupe velikih psihijatara i psihoterapeuta koji su pokrenuli integrativne ideje u psihoterapiji ${ }^{8}$ postojalo je izraženo i rašireno uvjerenje da pojedine psihološke i psihoterapeutske metode i škole imaju osobnu vrijednost koja se odražava u specifičnom utjecaju na klijente i u specifičnoj efikasnosti pojedinih psihoterapeutskih intervencija. Yalomovi popularni filozofski romani otvorili su psihijatriju ne samo široj javnosti nego su pokazali i njezinu filozofsku suštinu i razotkrili unutrašnje dileme i skrivene motive psihoterapeuta (posebno Yalom, 1997). Verhaeghe je, s druge strane, svojom epohalnom knjigom i priručnikom za psihoterapiju pod naslovom On being normal and other disorders, radikalno doveo u pitanje samobitnost psihijatrije kao discipline i otvorio suvremenu debatu o budućnosti psihoterapije s točke gledišta lacanovske psihoanalize i filozofije (Verhaeghe, 2018). Psihijatri Thomas Lewis, Fari Amini i Richard Lennon su 2000. godine objavili novu revolucionarnu knjigu pod naslovom A general theory of love kojom dovode u pitanje ideju samostalne vrijednosti psihoterapeutskih škola (Lewis et al., 2000). Sumirajući obilna empirijska istraživanja usmjerena na ocjenu uspjeha mnogobrojnih psihoterapeutskih škola i metoda, Lewis i njegovi koautori su došli do zaključka da zadovoljstvo klijenta psihoterapijom ili uspjeh psihoterapije u srednjoročnom periodu nemaju apsolutno nikakve veze sa »školom《 ili »metodom« kojoj pojedini psihoterapeuti pripadaju, nego isključivo ovise o individualnom i osobnom odnosu psihoterapeuta s klijentom, dakle od osobnih resursa psihoterapeuta i njegove vještine u uspostavi suradnje $s$ klijentom. Raspodjela najuspješnijih slučajeva ni na koji način nije ukazivala na dominaciju bilo koje škole. Naprotiv, ona je pokazivala da obuka psihoterapeuta ustvari služi isključivo osobnom samorazvoju i izgradnji psihoterapeuta, bez obzira na školu i metodu, te da je njihov kasniji uspjeh ovisio o tome u kojoj su mjeri, polazeći od bilo koje škole, u sebi uspjeli razviti potencijal, vrijednosti i vještine za uspostavljanje osobnog kontakta i spremnosti na žrtvu i sudjelovanje u često tegobnom i traumatičnom unutrašnjem životu svojih klijenata.

Jedan od načelnih razloga zbog kojih je tradicionalna psihoterapija u velikoj mjeri izgubila svoju samostalnost u odnosu na filozofiju jest isti kao razlog za krizu autoriteta psihijatrije: razlog je sasvim lacanovski i sastoji se u inzistiranju na nekoj vrsti pretpostavke o osobnoj »ekspertizi«, odnosno u onome što Lacan naziva master diskursom. Master diskurs je diskurs liječnika u odnosu na pacijenta. U tom diskursu liječnik polazi od pretpostavke da je on »stručan« za prepoznavanje pacijentovih problema te da je stručan za procjenu onoga što je najbolje za pacijenta, a pacijent polazi od toga da će, postupanjem po preporukama liječnika, poboljšati svoje stanje. Kada je riječ o mentalnim tegobama, ova je vrsta diskursa pogubna. Naime, kako je pokazalo iskustvo u najvećem broju slučajeva, ni liječnik ni psihoterapeut nisu »stručni« u punoj

Poput Irvina Yaloma ili Paula Verhaeghea. 
mjeri razumjeti individualni unutrašnji svijet pacijenta ili klijenta rukovodeći se medicinskim načinom mišljenja i medicinskom dijagnostikom o kojoj je bilo riječi na početku ovog teksta. Istovremeno, sama pretpostavka o tome da je u psihoterapeutskom razgovoru jedan sudionik »stručnjak « (lacanovskim jezikom »majstor«), a drugi laik za osobno iskustva, potpuno je neodrživa. Stoga Lacan svaku terapiju zasnovanu na master diskursu smatra frivolnom i unaprijed neuspješnom. Verhaeghe primjećuje da je »pozicija kliničkog direktora više dijagnoza nego radno mjesto «, kada se radi o psihijatrijskim ustanovama. Sama pretpostavka da se u psihodijagnostici i psihoterapiji može uspostaviti hijerarhija ekspertize u odnosu na pacijenta ili klijenta mučila je istaknute psihijatre i psihoterapeute desetljećima jer se u iskustvu pokazala kao neodrživa. Upravo se zato i ukazala potreba za novom paradigmom u psihoterapiji koja polazi od ravnopravnog, filozofskog diskursa bez očekivanja »ekspertize«, ali koji je zasnovan na jasnim logičkim i vrijednosnim pretpostavkama i omogućava da se sa pojedincem surađuje kao s ravnopravnom osobom kojoj je trenutno potrebna pomoć. Pri tome je sasvim vjerojatno da će, kroz pomagalački proces, pomagač pomoći i sebi samom te riješiti i neke svoje tegobe i nedoumice.

Norveški filozof i jedan od pionira pokreta filozofskih praktičara, Anders Lindseth, u tekstu u kojem govori o mentalnoj bolesti kao životnom iskustvu ovu paradigmu opisuje kao situaciju u kojoj netko, krećući se životnim putem, naiđe na prepreku koju ne može preći i nemajući drugog izbora za nastavak svog života skrene s puta da bi obišao prepreku. Na tom putu kroz gustiš i šiblje pored puta ponekad se izgubi i ostane u bespuću, naizmjenično pozivajući u pomoć i padajući u očajanje. Spomenuta egzistencijska izgubljenost možda se može doživljajno smanjiti upotrebom lijekova. Izgubljeni će čovjek vjerojatno biti manje uplašen nakon što dobije »farmakoterapiju«, ali jedini način da se on zaista spasi jest, kako kaže Lindseth, u tome da ga pronađe druga osoba, koja je također sišla s utabanog puta i potraži ga u bespuću (riskirajući pri tome svoj životni put) te ga dovede iza prepreke, natrag na put. U tome se ogleda ljudska ljubav, empatija, ali i žrtva koju psihoterapeut čini. U tome se očituje i perspektiva koja jasno ilustrira zbog čega je inzistiranje na »majstorskom « statusu, na master diskursu, apsurdno u području mentalnih teškoća i njihovog rješavanja. Lindseth govori o mentalnoj bolesti kao nedostatku energije za pobunu protiv okolnosti koje nije moguće podnijeti:

»Očaj zahtijeva energiju pobune. Međutim, kad smo bolesni, možemo postati preslabi da bismo se pobunili. Više ne uspijevamo pobjeći od boli, i tako postaje dovoljno bolno da dovede do pomirenja - sa samim sobom, s našim bližnjima, sa životom. To možemo nazvati misterijem pomirenja. To je također i utjeha.« (Lindseth, 2015: 58)

Integrativna psihoterapija kao psihoterapija današnjice zasniva se na svim opisanim uvidima i shodno tome na ideji da kvalitetna psihoterapija potječe iz istih onih osobnih resursa i filozofskih znanja i uvida psihoterapeuta koji su u korijenu kvalitetne teorije rukovođenja i leadershipa. Ona počiva na kritičkoj filozofiji kao početnoj točci razvoja praktične discipline savjetovanja i u svojoj dinamici i metodologiji ostaje uvijek na tragu filozofskog dijaloga. Taj dijalog izbjegava bilo kakav master diskurs u lacanovskom smislu, rezerviran je prema bilo kakvoj stigmatizaciji i označavanju različitosti kao »bolesti« te svaki jouissance ${ }^{9}$ kritički sagledava kao filozofsku temu. Iz ove vrste opće orijentacije proizlazi i osnovni »metodološki« princip integrativne psihoterapije $\mathrm{u}$ formi filozofskog savjetovanja, a to je princip prema kojem klijent uspostavlja kontrolu nad svojom teškoćom i počinje ispoljavati moć nad njom, onog trenutka kada tu teškoću uspije pretvori u temu filozofskog 
i pretežno racionalnog diskursa. Čim tema postane predmet filozofskog diskursa, ona prestaje biti bolest ili stigma i postaje izazov za interpretaciju. Navedeni prostor za interpretaciju tada otvara široke mogućnosti za primjenu, kako različitih filozofskih perspektiva od strane integrativnog terapeuta ili filozofskog praktičara tako i za klijentovo sagledavanje osobne egzistencijalne situacije u različitim filozofskim značenjima. U lacanovskom smislu, ta vrsta tranzicije iz perspektive »suhe patnje« u perspektivu ispoljavanja moći nad svojim problemom kao temom filozofskog razgovora omogućava i razvija obogaćivanje samog onog Simboličkog koje utjelovljuje psihičko zdravlje. Možda je ova podudarnost između samog duha, bića i aspiracija filozofske prakse $u$ formi integrativne psihoterapije, $s$ jedne strane, i lacanovske psihoanalize, s druge strane, istovremeno i razlog što se, usporedno s razvijanjem integrativne psihoterapije i srastanjem klasične psihoterapije s njom, u danas dominantno pozitivističku psihijatriju sve više vraća klasična lacanovska psihijatrija i psihoanaliza.

Bitna karakteristika integrativne psihoterapije jedna je vrsta uopćavanja općih uzroka psihopatologije. Lindsethovi argumenti, na tragu Lacanovih signifiera, ukazuju na reaktivnu prirodu psihopatologije u odnosu na pojmovnu konfuziju i nemogućnost produktivne interpretacije iskustva, naime na realnost da je zalaženje osobnosti u patologiju odgovor na nesavladivo životno iskustvo. ${ }^{10}$ Ti argumenti upućuju na potrebu dovođenja u vezu tegoba velikog broja ljudi s nekim općim, za sve zajedničkim iskustvima. Jedno je od ključnih takvih općih iskustava iskustvo straha. Integrativno razumijevanje straha podrazumijeva, na primjer, razmatranje različitih posljedica straha u domeni psihopatologije, dakle proces suprotan medicinskoj dijagnostici mentalnih poremećaja, pri kojemu se polazi od simptoma i potom traži njihov izvor. Integrativna psihoterapija tako je u bitnom smislu preventivna: ona traga za patološkim utjecajima iskustava kroz filozofsko preispitivanje života, tj. pretpostavki onoga što nazivamo »dobrim životom«. Ideja koja motivira ovu vrstu terapeutskog mišljenja je ta da »loš« ili »nedovoljno dobar« život generira nesavladiva iskustva koja dovode do upuštanja (s elementom slobodne volje) u psihopatologiju. Shodno tome, filozofsko poboljšanje života njegovim ispitivanjem, poput preispitivanja izvora egzistencijalnog straha kao jedne široko rasprostranjene »sirove emocije«, suzbija izvore patologije. Ovo razumijevanje istovremeno je duboko lacanovsko jer izbjegava dramatiziranje momenta duševnog obolijevanja. Ono polazi od pretpostavke da je duševna patologija u svima nama, kao latentno stanje, i da je pitanje o tome kakav život vodimo i kako pristupamo svojim iskustvima, koju konceptualnu matricu koristimo za interpretaciju tih iskustava određujuće za to hoće li se i koja patologija ispoljiti. Dakle, naglasak nije na »čistoj« razlici između duševnog zdravlja i duševne oboljelosti, nego na upravljanju životnim procesom i procesom interpretacije životnog iskustva koje će, ako je kvalitetno, smanjivati uvijek već prisutnu latentnu patologiju i činiti osobnost zdravijom. Integrativna psihoterapija primjenjuje isti pristup u liječenju, odnosno rješavanju problema koji potječu iz manifesnog mentalnog poremećaja: ona polazi od filozofskog stava da mentalni poremećaj, kao i duševno zdravlje, imaju svoju logiku te da se na njih može utjecati samo unutar te logike, a ne izvana intervencijama u odnosu na raspoloženja i funkcionalnost (poput intervenci-

Ili satisfakciju koja prati većinu svjesnih izbora koje pravi kako klijent, tako i savjetnik ili terapeut.
10

Dakle, da to iskustvo nije samo »okidač« mentalnog poremećaja nego i njegov autentični uzrok. 
je farmakoterapijom). Upravo je iz tog razloga integrativna psihoterapija po svojoj suštini filozofska i obuhvatna u odnosu na čitavu filozofsku tradiciju i metodološki instrumentarij. Ona objedinjuje suvremene spoznaje o irelevantnosti psihoterapeutskih škola u smislu efikasnosti terapije, lacanovsko razumijevanje latentne psihoze i konceptualne uvjetovanosti svih duševnih poremećaja, a duševnu bolest sagledava kao suštinski narativni fenomen, a ne klasičnu medicinski shvaćenu bolest. Samim time, ona »pacijenta« ili »klijenta« stavlja u kritičku, osnažujuću poziciju aktivnog ispitivača konceptualnih pretpostavki osobne tegobe $\mathrm{u}$ širokom filozofskom smislu, upravo na tragu praktične interpretacije filozofije koja njedri suvremenu filozofsku praksu, a koju je tako utjecajno formulirao Pierre Hadot (Pierre Hadot, 1995) svojom reinterpretacijom antičke filozofije kao u osnovi praktične filozofije, pri čemu su kozmologija, metafizika, pa i logika, samo »superstruktura« za suštinski integrativne, obuhvaćajuće i životne preokupacije filozofije kao suštinski terapeutske discipline.

\section{Literatura}

Hadot, P.; Davidson, A. I. (1995). Philosophy as a way of life: Spiritual exercises from Socrates to Foucault. Preveo: Chase, M. Oxford: Blackwell.

Kant, I. (1956). Kritika praktičnoga uma. Preveo: Sonnenfeld, V. D. Zagreb: Kultura.

Lacan, J. (2014). Anxiety. The seminar of Jacques Lacan. Book X. Preveo: Price, A. R. Cambridge: Polity.

Lewis, T.; Amini, F.; Lannon, R. (2000). A general theory of love. New York: Vintage.

Lindseth, A. (2015). »Being ill as an inevitable life topic. Possibilities of philosophical practice in health care and psychotherapy«. U: Weiss, M. N. (ur.). The Socratic Handbook. Dialogue Methods for Philosophical Practice, str. 47-66. Oslo: Lit Verlag.

Raabe, P. B. (2014). Philosophy's role in counseling and psychotherapy. Maryland: Rowman \& Littlefield.

Redmond, J. (2014). Ordinary Psychosis and The Body. London: Palgrave Macmillan.

Rosenhan, D. L. (1975). »The contextual nature of psychiatric diagnosis«. Journal of Abnormal Psychology 84 (1975) 5, str. 462-474. doi: http://doi.org/10.1037/h0077123.

Rosenhan, D. L. (1973). »On Being Sane in Insane Places«. Science 179 (1973) 4070, str. 250-258. doi: https://doi.org/10.1126/science.179.4070.250.

Schechtman, M. (2011). »The narrative self«. U: Gallagher, S. (ur.). Oxford Handbook of the Self, str. 391-417. Oxford: Oxford University Press. doi: https://doi.org/10.1093/oxfordhb/9780199548019.003.0018.

Schopenhauer, A. (1969). The world as will and representation. Prijevod: Payne, E. F. J. New York: Dover Publications.

Van Lieshout, P.; Brook, G.; Van Dijk, P. (1987). „Consistentie van psychiatrische diagnosen. Mededelingen uit het Patiëntenregister Intramurale Geestelijke Gezondheidszorg (20)«. Tijdschrift voor Psychiatrie 29 (1987) 4, str. 232-244.

Verhaeghe, P. (2018). On being normal and other disorders. A manual for clinical psychodiagnostics. London: Taylor and Francis. doi: https://doi.org/10.4324/9780429477768.

Wolf, B. (2015). Lacanian coordinates. From the logic of the signifier to the paradoxes of guilt and desire. London: Routledge. doi: https://doi.org/10.4324/9780429476518.

Yalom, I. D. (1997). Lying on the couch. A novel. New York: HarperPerennial. 


\title{
Aleksandar Fatić
}

\section{Representation and Pathology in Philosophy and Psychotherapy}

\begin{abstract}
The paper discusses the conceptualisation of mental disorder as a representation, rather than an illness, and relates this perspective to the modern understanding of mental health as a healthy "narrative" or life story. The author proceeds to briefly consider the evolution of concepts of illness in psychiatry and a gradual reappearance of Lacanian psychoanalysis and psychiatry. The key concepts of Lacanian psychotherapy pave the way to a growing together of standard psychotherapy and modern philosophical practice within the novel concept of integrative psychotherapy.
\end{abstract}

\section{Key words}

integrative psychotherapy, mental disorder, Lacanian psychoanalysis, philosophical practice 